\title{
Plant diversity and dynamics in chalk quarries on the islands of Rügen and Wolin (Western Pomerania/Germany and Poland)
}

\section{Peter König}

Institute of Botany and Landscape Ecology, Botanic Garden, University of Greifswald, Soldmannstraße 15, D-17489 Greifswald, Germany, e-mail: pkoenig@uni-greifswald.de

\begin{abstract}
Chalk mining industry in Western Pomerania reflects a history of almost 300 years, and has left behind a typical post-mining landscape. Thus, more than 50 formerly exploited areas are known on the islands of Rügen and Wolin. Historical quarry sizes range from 0.1 to 42 hectares, the median is 1.3 . Chalk quarries are recolonised by a wide range of species and develop attractive and species-rich communities. To the extent that recolonisation progresses, they act as refugia for rare or local species. Currently, a total of 543 vascular plant species are found in these chalk quarries. Species number ranges from 97 to 218 in thoroughly studied sites, with a median of 138 . Of the total floristic inventory, $67 \%$ are indigenous species, $18 \%$ are archaeophytes and $12 \%$ neophytes. Quarries abandoned long ago and remotely situated are home to nearly $90 \%$ indigenophytes, whereas those quarries close to settlements or with easy access are tendentially characterised by numerous synanthropic plants. 100 species overall $(=18.4 \%)$ belong to Red List categories of Mecklenburg-Western Pomerania. In 22 quarries studied in more detail, Red List percentages show a spectrum from 3.7 to $23.5 \%$, and higher values are found in sites with open habitats and considerable biotope diversity. Among vegetation types, the anthropo-zoogenic heathland and grassland harbours $40 \%$ Red List species and occupies the first place concerning nature conservation aspects. A noteworthy percentage of endangered plants is found in fresh-water and bog vegetation, as some quarries are in contact with the aquifer. Succession was and is the impetus for vegetation development. A transect exemplarily demonstrates the vegetation zonation within a chalk quarry and distinguishes headslope, backslope, and footslope and the quarry floor. The respective plant communities are classified into Cornus sanguinea bush stage, Picris hieracioides-Daucus carota community, and basiphilous mesoxerophytic grassland.
\end{abstract}

Key words: secondary biotopes, post-mining landscape, chalk, mesoxerophytic grassland, succession, conservation

\section{Introduction}

Remarkable features of the Baltic Sea coast are the chalk deposits of Rügen Island (Germany) and elsewhere. This chalk is about 70 million years old. The chalk layer is particularly thick on the Jasmund Peninsula and is located close to the surface. The rich chalk deposits were long used locally as fertiliser (up to the end of the $19^{\text {th }}$ century) or - fired in chalk furnaces - as brick lime (such a furnace in Granitz, Rügen dates back to 1720). On the Island of Wolin (Poland), located in the Odra river mouth north of Szczecin, similar geological preconditions exist and have been known for more than 150 years in literature (Behrens 1878). Therefore, abandoned chalk quarries are present with close historical links to the Jasmund chalk mining industry (joint marketing in 1920s, processing of Rügen chalk in Poland after shipment from Sassnitz to Świnoujście).

In 1830 s, techniques were developed to process raw chalk to yield precipitated chalk, which is a refined product with multiple uses. Thereafter, a veritable founding boom took place on Rügen Island in 1840s and 1850s, with more than 50 former mining areas known in the area. Since 1962, only one large-scale mining factory with largely automatic processing has been operating in Klementelvitz, Jasmund. Precipitated chalk is used for paint, medical applications, and, especially, desulphurisation in power stations. Former chalk quarries in the southwestern part of Wolin Island (NW Poland) are located in Wicko (Vietzig), Lubin (Lebbin), Wapnica (Kalkofen) and Kępa (Kamp). The former quarry south of Wapnica is filled with water, forming a remarkable 

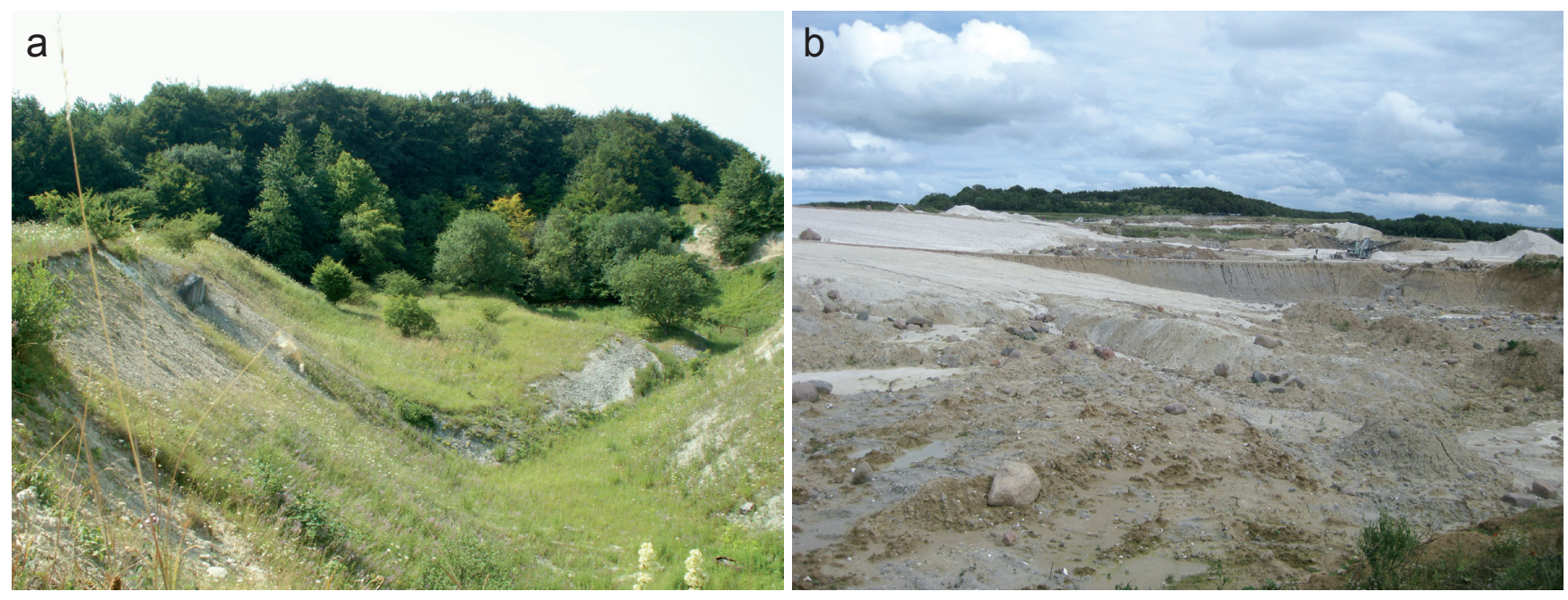

Fig. 1. Former small-scale Bonerberg chalk quarry (1 ha in area) (a) and present large-scale Promoisel quarry (300 ha) (b). Photographs by Peter König

Turquoise Lake (“Jezioro Turkusowe”), a popular recreation area today and part of Wolin National Park. The old chalk quarry ("Stara Kredownia") at Kępa is also located within the park boundaries and still accessible today.

Areas mined in former quarries were considerably smaller than those more recently worked, due to predominantly manual labor in earlier years (Fig. 1). The chalk museum ("Kreidemuseum") in Gummanz, Rügen impressively displays the historical mining technology and equipment. Some of the quarries, which have been abandoned for decades, are already forested and not evident on aerial photographs, while others have been converted to a water reservoir, storage or waste disposal sites. Other larger-scale restoration measures have not been conducted.

This is quite an important aspect, which has been stressed by various authors. Because traditional reclamation methods, in general, often destroy valuable ecological potential by equalizing site conditions, ameliorating of nutrient-poor substrates, or seeding and planting of species not perfectly suited to individual site conditions. In contrast, mining sites can regenerate spontaneously over long-term periods and offer a great deal of habitat conditions. Thus, the use of nature self-healing or self-regeneration capacity, which is cheap and effectively produces higher natural value, is more and more often resorted to as a new state-of-art approach in ecological restoration (Prach \& Pyšek 2001; Tischew \& Kirmer 2007). Baczyńska et al. (2017) focus simply on landscape attractiveness of abandoned and not technocratic restored quarries. Initially, most attention was focused on botanical relevance of abandoned quarries (Davis 1979; Jefferson 1984; Jefferson \& Usher 1989; Zerbe \& Schacht 1997,
1998), and zoological aspects followed somewhat later (Wheater \& Cullen 1997; Wheater et al. 2000). Meanwhile, limestones quarries are known as refuges for European xerophilous butterflies (Beneš et al. 2003). Thus, the quarries are remarkable remnants of the region's historical chalk mining industry, and are of ecological and cultural importance. They provide artificially created open landscapes with nutrient-poor soil, enabling the establishment of dry grassland communities with "marker species". Hence, various orchids rank among the specialities, e.g. Dactylorhiza fuchsii, Epipactis atrorubens, and E. palustris. Today, reforestation by succession is obvious. More detailed botanical studies were presented by Zerbe \& Schacht $(1997,1998)$ and König et al. (2005) for the Jasmund chalk quarries, while relevant Wolin sites found attention mainly thanks to geologists and their findings of faunistic fossils (Reich 2001; Reich \& Wiese 2010), classifying the Wolin outcrops as loci typici of the Upper Cretaceous due to numerous new species described from these sites.

Plant communities of the abandoned chalk quarries may be classified into the following categories:

(1) Pioneer vegetation: Poo-Tussilaginetum on steep slopes, site conditions shaped by erosion, Poa compressa and Tussilago farfara among the typical representatives.

(2) Grassland and scrub vegetation: Mesobromion communities with Briza media, Carex flacca, Origanum vulgare, Parnassia palustris; Dauco-Arrhenatheretum, partly with tall perennial herbs; Rhamno-Cornetum (scrub with Crataegus spp., Cornus sanguinea, Prunus spinosa and/or Rhamnus cathartica) and Hippophaë rhamnoides propagate easily between the slopes.

(3) Forest vegetation: thermophilous or mesophytic Beech Forest (Cephalanthero-Fagenion, Galio-Fage- 
nion). Indicator species are: Actaea spicata, Cephalanthera damasonium, Dentaria bulbifera, Lathraea squamaria, Melica uniflora, Mercurialis perennis, Neottia nidus-avis, representing mature forest associations. (4) Aquatic and swamp vegetation: Cutting aquifers in the mining process led to the formation of ponds with Nymphaea alba and Potamogeton spp. among the floating plants and Typhetum and various Caricetum communities in the reed belt. Temporarily flooded sites are occupied by Salix bushes.

This study addresses the following main questions: How many fern and flowering plant species are able to gain a foothold in the former quarries? What are the species groups colonising the former quarries? Upon which factors does the specific species composition depend? What is the human influence? Do the quarries harbour noteworthy numbers of endangered plant species and which biotopes contain the bulk of Red Data Book species? What is the influence of the mining period and its intensity on recent successional stages?

\section{Study sites and history}

The main study area is situated on the Jasmund Peninsula of Rügen Island, Germany, with an additional study site on Wolin Island, Poland (Fig. 2). The history of chalk mining in the southern Baltic Sea region, as far as it is helpful in the understanding of successional processes, is briefly summarised below (cf. Weber 1956, 1970; Kutscher 1998):

1720 - First chalk quarry on southern Rügen, raw chalk was used locally as brick mortar and fertiliser. Thus, chalk has been mined on Rügen for nearly 300 years.

1845 - The first precipitated chalk factory was established on the Jasmund Peninsula (in Krampas, since 1906 part of Sassnitz). The number of precipitated chalk factories increased to 10 in 1866 and 23 in 1885 , with a decline to 19 in 1956.

1870s - Additional raw chalk quarries were founded due to the demand in the cement industry. The main customers were cement factories in the Oder estuary region, which had exploited the chalk deposits at Wolin, Usedom, and northern Szczecin since the 1850s. After their exhaustion, Rügen chalk took their place.

To 1939 - Before World War 2, Wapnica (pre-war name "Kalkofen") was one of the largest centres of chalk mining in Germany due to easy access and processing of the soft chalk to cement.

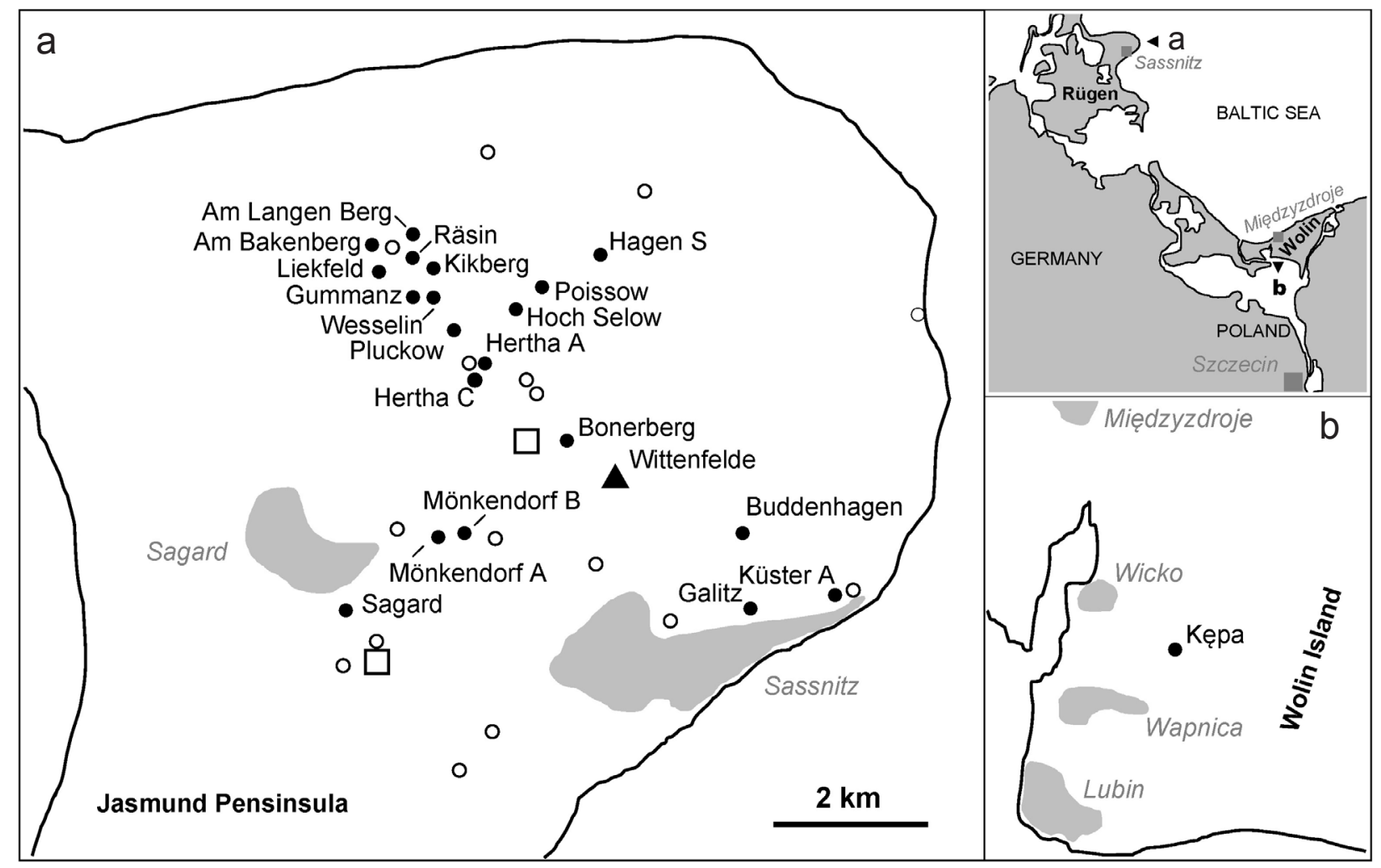

Fig. 2. Study areas in Western Pomerania on the Jasmund Peninsula (a) and Wolin Island (b)

Explanations: former chalk quarries, $\bullet$ - investigated in detail, $\circ$ - not investigated in detail; $\boldsymbol{\Delta}$ - the abandoned large-scale Wittenfelde quarry; $\square-$ current mining (Promoisel west of Bonerberg) or exploration areas (Goldberg near Sagard) 


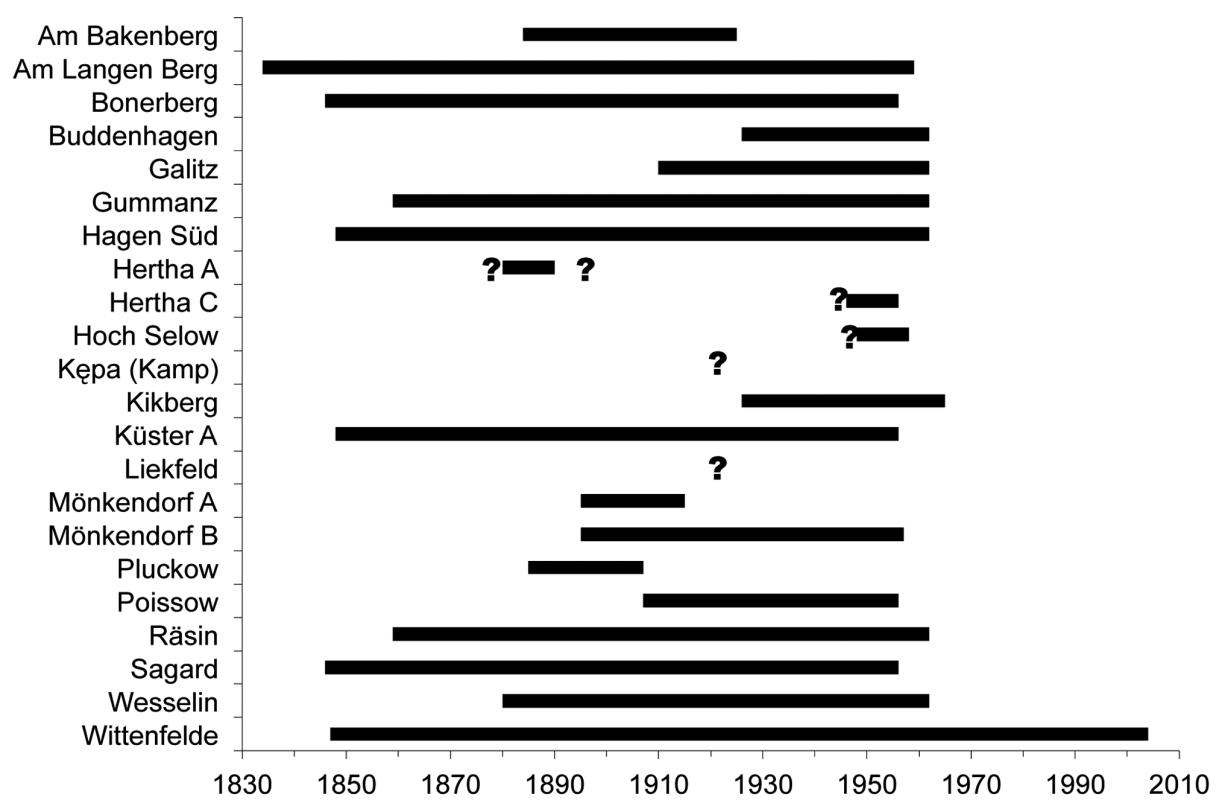

Fig. 3. Former Jasmund and Wolin chalk quarries studied in detail and their exploitation periods, adapted from Koch (1934), Weber (1956, 1970), and data from "Kreidemuseum" (chalk museum) in Gummanz

Explanation: ? - no further data available

After 1945 - Former Pomeranian cement factories ceased to be main customers; instead, the central German cement factories were supplied with raw material from Rüdersdorf (near Berlin) and other deposits. Consequently, the mined chalk was nearly completely converted to precipitated chalk and the demands of the market increased continuously due to the product high quality and numerous applications.

1950s - First diggers/shovel excavators were used and mining converted gradually to large-scale processing.

To 1962 - It took at least five weeks from mining to delivery of the chalk barrels due to air drying of the chalk.

After 1962 - A modern, state-owned, large-scale Wittenfelde chalk quarry was established in Klementelvitz and exploited until 2004. As a result, the small-scale quarries were quickly abandoned. Currently, large-scale mining is done in Promoisel (300 hectares) and processing requires only 80 minutes from mining to delivery.

The mining periods of the studied quarries are depicted in Fig. 3.

\section{Material and methods}

The floristic data pool (ferns and flowering plants, subsequently referred to as "plants") was recorded mainly from 2003 to 2015 . Additionally, the pertinent literature was evaluated, e.g. Kutscher (1997a), Zerbe \& Schacht (1997, 1998), König et al. (2005). Thus, the total time span included in the floristic inventory comprises a period of about 20 years. The nomenclature follows Jäger (2011). The assignment to the period of introduction to Mecklenburg-Western Pomerania (i.e. the classification into indigenous, archaeophytic and neophytic species) was based on Fukarek \& Henker (2006), regardless of the Polish study site at Wolin (Mirek et al. 2002 classify the floristic resources of Poland overall merely into anthropophytes and ephemerophytes). But the uniform natural area and settlement history of Western Pomerania justifies this approach. The same applies to Voigtländer \& Henker (2005) for the affiliation of endangered plant species in the quarries. This Red Data Book presents the local conditions on a small-scale basis quite well. A somewhat comparable Red List of northwest Poland by Żukowski \& Jackowiak (1995) follows a less sensitive estimate. The Red List of vascular plants in Poland by Kaźmierczakowa et al. (2016) is larger-scaled; the same applies to the German equivalent by Korneck et al. (1996).

Altogether, 42 quarries were inspected, 38 were surveyed for higher plants, and 22 were subjected to a more comprehensive survey with a sampling frequency $\geq 2$, i.e., data from different years and seasons are available (multiple visits). The latter data are predominantly used for the result section. For the determination of the area size, the quarry's edge was used as the boundary. Nevertheless, the delimitation 
is somewhat arbitrary and the area size (in hectares) represents rough estimates.

The presented quarry transect (out of a total of five) was conducted along a $20 \mathrm{~m} \times 5 \mathrm{~m}\left(100 \mathrm{~m}^{2}\right)$ slope and consisted of sections and grids. The grids chosen had an area of $1 \mathrm{~m}^{2}(1 \mathrm{~m} \times 1 \mathrm{~m})$, reflecting the vegetation units to be recorded quite well. In each grid, presence/ absence data of plants were recorded. Every section comprised five grids; thus, relative frequency per section ranged from one to five. Altogether, 20 sections were analysed within the Pluckow example. A transect technique enabled a continuous survey and was unaffected from any homogeneity requirements. The data were additionally subjected to a hierarchical cluster

Table 1. Size, utilisation and biotope types of the Jasmund and Wolin chalk quarries

\begin{tabular}{|c|c|c|c|c|c|c|c|c|c|c|c|}
\hline Quarry name & 1 & 2 & 3 & 4 & 5 & 6 & 7 & 8 & 9 & 10 & 11 \\
\hline Alter Bruch & 0.7 & - & $\bullet$ & - & - & - & - & - & $\bullet$ & $\bullet$ & - \\
\hline Am Bakenberg & 0.6 & - & - & - & - & - & - & - & - & $\bullet$ & 120 \\
\hline Am Langen Berg & 0.6 & - & - & - & - & $\circ$ & $\bullet$ & - & $\bullet$ & $\bullet$ & 166 \\
\hline Blieschow & 0.4 & - & - & - & - & $\circ$ & $\bullet$ & ० & $\bullet$ & - & - \\
\hline Bonerberg & 1.0 & - & - & $\bullet$ & $\bullet$ & $\bullet$ & $\bullet$ & - & $\bullet$ & - & 149 \\
\hline Buddenhagen & 1.3 & $\Delta$ & - & $\bullet$ & $\bullet$ & $\circ$ & $\bullet$ & $\bullet$ & o & $\bullet$ & 131 \\
\hline Drosevitz & 0.3 & - & - & - & - & $\bullet$ & - & - & $\bullet$ & $\bullet$ & - \\
\hline Dubnitz & 0.1 & - & - & - & - & - & - & - & ○ & $\bullet$ & - \\
\hline Galitz & 6.0 & - & $\bullet$ & $\bullet$ & $\bullet$ & $\bullet$ & - & - & $\bullet$ & ० & 162 \\
\hline Goldberg & 0.8 & - & - & $\bullet$ & $\bullet$ & - & $\bullet$ & - & $\bullet$ & - & - \\
\hline Gummanz & 3.0 & $\Delta$ & $\bullet$ & $\bullet$ & $\bullet$ & ० & $\bullet$ & $\bullet$ & $\bullet$ & $\bullet$ & 199 \\
\hline Hagen Nord & 0.3 & $\Delta$ & - & - & - & $\circ$ & $\bullet$ & $\bullet$ & - & - & - \\
\hline Hagen Süd & 1.5 & - & $\bullet$ & $\bullet$ & $\bullet$ & $\bullet$ & $\bullet$ & - & $\bullet$ & $\bullet$ & 177 \\
\hline Halde an der Waldschule Sassnitz & 0.4 & - & - & - & - & - & - & - & $\bullet$ & $\bullet$ & - \\
\hline Hertha A & 0.4 & - & $\bullet$ & - & - & - & - & - & $\bullet$ & $\bullet$ & 104 \\
\hline Hertha B & 0.3 & - & - & - & - & - & - & - & $\bullet$ & $\bullet$ & - \\
\hline Hertha C & 0.7 & - & ○ & $\bullet$ & $\bullet$ & $\bullet$ & $\circ$ & - & $\bullet$ & ० & 131 \\
\hline Hoch Selow & 3.7 & - & $\bullet$ & $\circ$ & $\circ$ & $\circ$ & $\bullet$ & - & $\bullet$ & ० & 217 \\
\hline Kępa (Kamp) & 1.0 & - & - & $\bullet$ & $\bullet$ & $\bullet$ & $\bullet$ & - & $\bullet$ & ○ & 107 \\
\hline Kieler Ufer & 0.1 & - & ○ & - & - & - & - & - & - & $\bullet$ & - \\
\hline Kikberg & 0.8 & - & - & $\bullet$ & $\bullet$ & $\bullet$ & $\bullet$ & - & $\bullet$ & ० & 113 \\
\hline Küster A & 2.0 & - & $\bullet$ & $\bullet$ & $\bullet$ & $\bullet$ & $\bullet$ & - & $\bullet$ & - & 97 \\
\hline Küster B & 1.0 & - & $\bullet$ & $\bullet$ & $\bullet$ & - & - & - & $\bullet$ & $\bullet$ & - \\
\hline Lancken I & 5.9 & - & $\bullet$ & $\circ$ & o & $\circ$ & - & - & $\bullet$ & $\bullet$ & - \\
\hline Lancken II & 4.1 & $\Delta$ & - & - & - & - & - & - & - & - & - \\
\hline Lenzberg & 1.8 & $\Delta$ & - & $\bullet$ & $\bullet$ & - & - & $\bullet$ & $\bullet$ & $\bullet$ & - \\
\hline Liekfeld & 1.3 & - & - & $\bullet$ & $\bullet$ & $\bullet$ & - & o & $\bullet$ & - & 137 \\
\hline Mönkendorf A & 3.3 & - & ○ & - & - & - & ○ & $\bullet$ & $\bullet$ & $\bullet$ & 108 \\
\hline Mönkendorf B & 10 & - & $\bullet$ & $\bullet$ & $\bullet$ & ० & $\bullet$ & - & $\bullet$ & $\bullet$ & 138 \\
\hline Mönkendorf C & 7.6 & $\Delta$ & $\bullet$ & $\bullet$ & $\bullet$ & $\bullet$ & $\bullet$ & - & $\bullet$ & $\bullet$ & - \\
\hline Nipmerow & 1.5 & - & $\bullet$ & - & - & - & $\bullet$ & - & $\bullet$ & $\bullet$ & - \\
\hline Pluckow & 1.5 & - & - & $\bullet$ & $\bullet$ & $\bullet$ & $\bullet$ & $\bullet$ & $\bullet$ & $\bullet$ & 161 \\
\hline Poissow & 0.8 & - & $\bullet$ & $\circ$ & ० & $\circ$ & $\bullet$ & $\bullet$ & $\bullet$ & $\bullet$ & 121 \\
\hline Promoisel & 300 & $\Delta$ & - & $\bullet$ & $\bullet$ & - & - & - & - & - & - \\
\hline Promoisel A & 1.4 & - & $\bullet$ & - & - & $\bullet$ & $\bullet$ & - & ○ & $\bullet$ & - \\
\hline Promoisel B & 1.1 & - & $\bullet$ & - & - & - & - & - & - & $\bullet$ & - \\
\hline Quatzendorf & 4.8 & $\Delta$ & $\bullet$ & - & - & - & $\bullet$ & - & $\bullet$ & $\bullet$ & - \\
\hline Räsin & 2.0 & - & $\bullet$ & $\bullet$ & $\bullet$ & $\bullet$ & - & - & $\bullet$ & - & 189 \\
\hline Sagard & 1.2 & - & $\bullet$ & $\circ$ & - & - & $\bullet$ & $\bullet$ & $\bullet$ & $\bullet$ & 118 \\
\hline Sehlitz & 5.3 & $\Delta$ & $\bullet$ & - & - & - & - & - & $\bullet$ & $\bullet$ & - \\
\hline Wesselin & 1.1 & - & - & $\bullet$ & $\bullet$ & $\bullet$ & ○ & - & $\bullet$ & $\bullet$ & 157 \\
\hline Wittenfelde & 42 & - & $\bullet$ & $\bullet$ & $\bullet$ & $\bullet$ & $\bullet$ & - & $\bullet$ & - & 217 \\
\hline the number of cases & 42 & 9 & 20 & 20 & 20 & 15 & 21 & 8 & 33 & 27 & 22 \\
\hline
\end{tabular}

Explanations: 1 - quarry size in hectares, 2 - technical use, 3-10 biotope types: 3 - waters, 4 - lithosol, 5 - pioneer vegetation, 6 - oligotrophic grassland, 7 - other grasslands, 8 - perennial herb communities, 9 - scrub, 10 - forest, 11 - number of species (only quarries with a sampling frequency $\geq 2$ included),

$\mathbf{\Delta}$ - present, $\bullet$ - extensively present, $\bigcirc$ - minor patches, - not present 
analysis using the statistics software SPSS, to clarify the spatial distribution patterns of the transect vegetation. Every grid of each transect was treated as a single case or single cluster within this analysis. Different variables of a case were different plant species occurring in this grid.

Pairwise comparison of the quarry species lists was performed using Sørenson's coefficient of similarity (similarity index): $\mathrm{C}_{\mathrm{s}}=2 \mathrm{j} /(\mathrm{a}+\mathrm{b})$, where $j$ is the number of species common to the two samples and $a$ and $b$ are the total number of species in each sample, respectively. This is a simple measure of the extent to which the two samples have species in common.

Soil samples were analysed for lime and organic content in selected transects to obtain an overview of hitherto not well known edaphic parameters in different quarry zones. Within a transect, two soil samples were collected from the first $10 \mathrm{~cm}$ of the topsoil in each of the three slope sections. The mean values are presented in the results section. Soil analysis was performed according to Schlichting et al. (1995).

\section{Results}

\subsection{Diversity of biotopes}

The present study covered 42 chalk quarries. These objects considerably differ in their areas, periods of use and methods of exploitation. As a result, they are highly differentiated in terms of their biotope types. The size of analysed objects ranges from 0.1 to 300 ha (Table 1, column 1). In nine quarries, a secondary technical use was evident (Table 1, column 2). Based on the author's observations, seven types of biotopes were distinguished in the analysed chalk quarries: waters, lithosol, pioneer vegetation, oligotrophic grassland, other grasslands, perennial herb communities, scrub and forest. These biotypes occur with different frequency. The most often are scrubs (33 objects) and forests (27), while the rarest - perennial herb communities (8). All types of biotopes occur in Gummanz and Poissnow, while in Am Bakenberg, only one type of biotope was present (forest).

\subsection{Plant diversity}

The total number of vascular plant species in the surveyed chalk quarries was 543 . In the 22 quarries studied in more detail and comprising the main basis of the statistical calculations below, 483 fern and flowering plant species were present. Brachypodium sylvaticum, Cornus sanguinea, Crataegus monogyna, Dactylis glomerata, Deschampsia cespitosa, Fraxinus excelsior, Hypericum perforatum, Origanum vulgare, Rubus caesius, Salix caprea and Urtica dioica showed a frequency of more than $90 \%$. A grouping of species into five frequency categories was done. Therefore, 53 species were nearly omnipresent (1822 quarries), and similar numbers of 47 (13-17) and $60(8-12)$ were typical for the intermediate constancy levels, while 138 species were represented in 3 to 7 quarries, and 185 species were found in only one or two quarries.

Species diversity within the quarries with a sampling frequency $\geq 2$ ranged from 97 to 218 ; the median was 138. The related quarry sizes ranged from 0.4 to about 42 hectares, with a median of 1.3 hectares (Fig. 4). The largest was in Wittenfelde used until 2004. In comparison, the mining area near Promoisel, newly established in 2004 but not surveyed, covers an exploration area of 300 hectares.

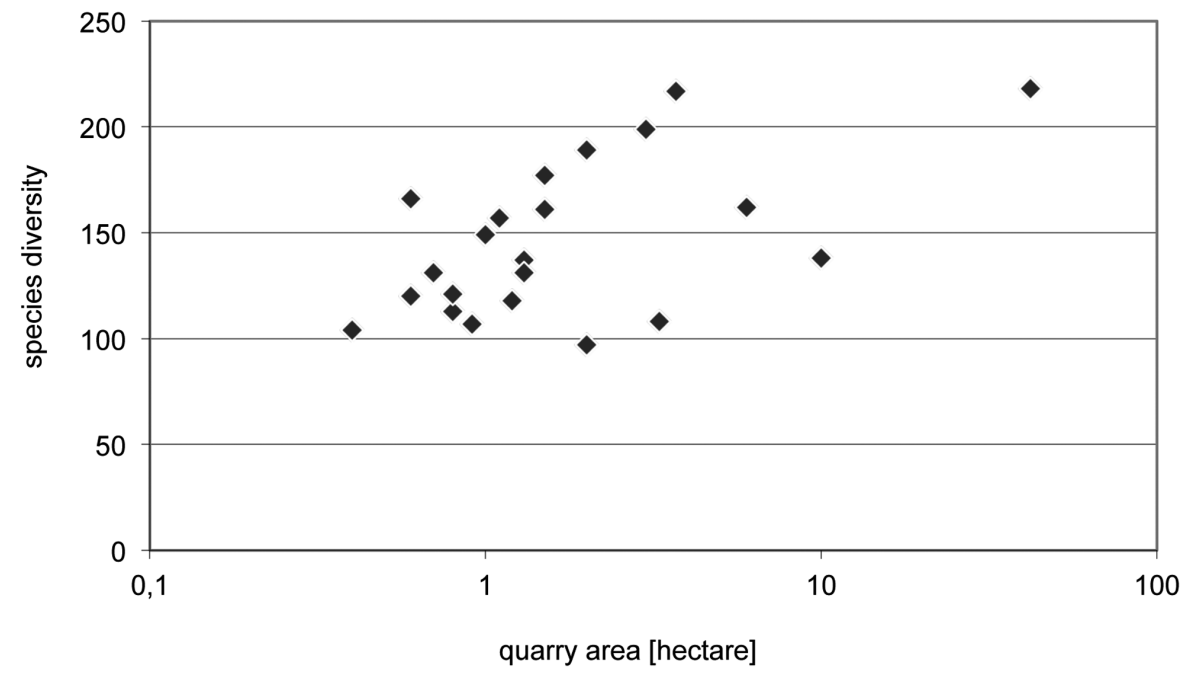

Fig. 4. Species diversity of 22 Jasmund and Wolin chalk quarries studied in detail ( 483 species of ferns and flowering plants in total) plotted against the size of the quarries with a sampling frequency $\geq 2$ (median -1.3 ha, quarry area in logarithmic scale) 
Table 2. Sørenson's similarity index for the 22 Jasmund and Wolin chalk quarries studied in detail

\begin{tabular}{|c|c|c|c|c|c|c|c|c|c|c|c|c|c|c|c|c|c|c|c|c|c|c|}
\hline Quarry name & 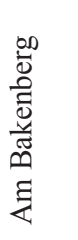 & 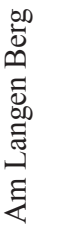 & 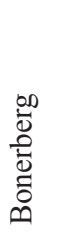 & 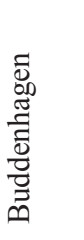 & $\stackrel{\stackrel{N}{\Xi}}{\stackrel{\Xi}{\Xi}}$ & 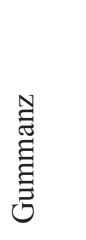 & $\begin{array}{l}\mathscr{N} \\
\widetilde{D} \\
\mathbb{D} \\
\mathbb{\Xi} \\
\mathbb{I}\end{array}$ & 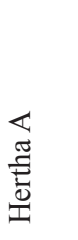 & 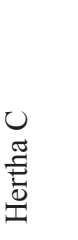 & $\begin{array}{l}3 \\
0 \\
0 \\
0 \\
0 \\
0 \\
0 \\
1\end{array}$ & 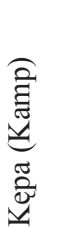 & 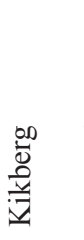 & 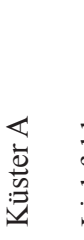 & 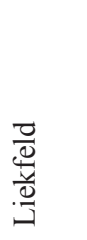 & 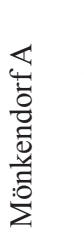 & 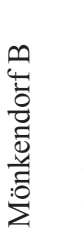 & $\begin{array}{l}\frac{3}{0} \\
\frac{0}{0} \\
\frac{\Xi}{0}\end{array}$ & $\begin{array}{l}3 \\
0 \\
0 \\
0 \\
0 \\
0 \\
0\end{array}$ & $\begin{array}{l}\stackrel{\Xi}{:} \\
: \stackrel{\text { a }}{\simeq}\end{array}$ & 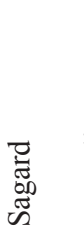 & $\begin{array}{l}\Xi \\
0 \\
\infty \\
\infty \\
0 \\
3\end{array}$ & 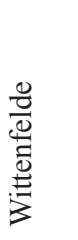 \\
\hline Am Bakenberg & $\square$ & 0.65 & 0.51 & 0.44 & 0.43 & 0.51 & 0.55 & 0.53 & 0.55 & 0.53 & 0.37 & 0.49 & 0.44 & 0.56 & 0.51 & 0.57 & 0.53 & 0.50 & 0.54 & 0.55 & 0.57 & 0.51 \\
\hline Am Langen Berg & & $\square$ & 0.60 & 0.56 & 0.56 & 0.62 & 0.66 & 0.44 & 0.59 & 0.57 & 0.45 & 0.57 & 0.51 & 0.63 & 0.41 & 0.50 & 0.67 & 0.58 & 0.68 & 0.49 & 0.71 & 0.58 \\
\hline Bonerberg & & & $\square$ & 0.56 & 0.63 & 0.61 & 0.67 & 0.51 & 0.64 & 0.54 & 0.46 & 0.65 & 0.57 & 0.66 & 0.40 & 0.53 & 0.74 & 0.63 & 0.64 & 0.55 & 0.67 & 0.64 \\
\hline Buddenhagen & & & & $\square$ & 0.61 & 0.54 & 0.60 & 0.38 & 0.54 & 0.51 & 0.45 & 0.55 & 0.61 & 0.63 & 0.41 & 0.47 & 0.65 & 0.59 & 0.56 & 0.52 & 0.57 & 0.51 \\
\hline Galitz & & & & & $\square$ & 0.59 & 0.59 & 0.41 & 0.55 & 0.51 & 0.51 & 0.55 & 0.66 & 0.62 & 0.35 & 0.49 & 0.66 & 0.56 & 0.62 & 0.50 & 0.58 & 0.61 \\
\hline Gummanz & & & & & & $\square$ & 0.67 & 0.48 & 0.65 & 0.64 & 0.46 & 0.59 & 0.51 & 0.64 & 0.45 & 0.53 & 0.69 & 0.61 & 0.76 & 0.50 & 0.74 & 0.68 \\
\hline Hagen S & & & & & & & $\square$ & 0.48 & 0.64 & 0.61 & 0.43 & 0.59 & 0.51 & 0.65 & 0.41 & 0.53 & 0.69 & 0.65 & 0.69 & 0.54 & 0.71 & 0.61 \\
\hline Hertha A & & & & & & & & $\square$ & 0.63 & 0.51 & 0.28 & 0.51 & 0.40 & 0.46 & 0.57 & 0.53 & 0.45 & 0.47 & 0.48 & 0.55 & 0.50 & 0.50 \\
\hline Hertha C & & & & & & & & & $\square$ & 0.61 & 0.45 & 0.64 & 0.54 & 0.60 & 0.49 & 0.57 & 0.62 & 0.66 & 0.64 & 0.59 & 0.64 & 0.64 \\
\hline Hoch Selow & & & & & & & & & & $\square$ & 0.40 & 0.53 & 0.45 & 0.55 & 0.48 & 0.60 & 0.60 & 0.56 & 0.64 & 0.53 & 0.57 & 0.61 \\
\hline Kępa (Kamp) & & & & & & & & & & & $\square$ & 0.48 & 0.48 & 0.48 & 0.27 & 0.39 & 0.51 & 0.46 & 0.49 & 0.38 & 0.51 & 0.45 \\
\hline Kikberg & & & & & & & & & & & & $\square$ & 0.54 & 0.69 & 0.42 & 0.50 & 0.66 & 0.62 & 0.62 & 0.56 & 0.70 & 0.53 \\
\hline Küster A & & & & & & & & & & & & & $\square$ & 0.60 & 0.36 & 0.49 & 0.57 & 0.59 & 0.54 & 0.47 & 0.55 & 0.48 \\
\hline Liekfeld & & & & & & & & & & & & & & $\square$ & 0.42 & 0.52 & 0.74 & 0.71 & 0.67 & 0.58 & 0.71 & 0.56 \\
\hline Mönkendorf A & & & & & & & & & & & & & & & $\square$ & 0.62 & 0.41 & 0.40 & 0.42 & 0.55 & 0.40 & 0.46 \\
\hline Mönkendorf B & & & & & & & & & & & & & & & & $\square$ & 0.53 & 0.50 & 0.53 & 0.56 & 0.52 & 0.56 \\
\hline Pluckow & & & & & & & & & & & & & & & & & $\square$ & 0.66 & 0.72 & 0.56 & 0.75 & 0.63 \\
\hline Poissow & & & & & & & & & & & & & & & & & & $\square$ & 0.60 & 0.58 & 0.64 & 0.55 \\
\hline Räsin & & & & & & & & & & & & & & & & & & & $\square$ & 0.51 & 0.73 & 0.65 \\
\hline Sagard & & & & & & & & & & & & & & & & & & & & $\square$ & 0.52 & 0.51 \\
\hline Wesselin & & & & & & & & & & & & & & & & & & & & & $\square$ & 0.60 \\
\hline Wittenfelde & & & & & & & & & & & & & & & & & & & & & & $\square$ \\
\hline Number of species & 120 & 166 & 149 & 131 & 162 & 199 & 177 & 104 & 131 & 217 & 107 & 113 & 97 & 137 & 108 & 138 & 161 & 121 & 189 & 118 & 157 & 217 \\
\hline
\end{tabular}

Explanations: values $>0.7$ are highlighted in black, values $<0.4$ in grey; minimum -0.27 , median and mean -0.55 each, maximum -0.76

Quarries with a similar succession stage and a similar set of biotopes formed a uniform block with higher similarity values, e.g. Am Langen Berg, Bonerberg, Gummanz, Hagen Süd, Liekfeld, Pluckow, Poissow, Räsin, Wesselin (black highlighting in Table 2). These sites were all characterised by open mesoxerophytic grassland and a mean stage of natural reforestation. It is noteworthy that quarries which are totally reforested and of similar appearance superficially, e.g. Am Bakenberg and Mönkendorf A, had obviously less in common according to their medium similarity index of 0.51 . The Kępa quarry on Wolin Island harboured a wellrepresented resources of mesoxerophytic grassland and exhibited little reforestation progress; nevertheless, similarity indices to the corresponding quarries of the Jasmund Peninsula were comparatively low due to sand lenses within the chalk and a diverging set of species. Thus, a great deal of individual variation resulted from differences in the location, history, and variability of the quarry itself and in the nature of the surrounding habitats.

\subsection{Origin of the chalk quarry flora}

Concerning the total floristic spectrum of chalk quarries according to their period of immigration or introduction, about two-thirds were indigenous species, $18 \%$ were archaeophytes and $12 \%$ neophytes (Fig. 5a). Remote quarries did not suffer from garden waste disposal as much as those situated close to settlements. Examples of taxa with a garden origin in the quarries comprised: Fallopia japonica, Hyacinthoides hispanica, Nepeta catarica, Phalaris arundinacea 'Picta', Rosa rugosa, Rubus armeniacus, Saponaria officinalis 'Rosea Plena', Stachys byzantina, Symphoricarpos albus, Syringa vulgaris. 


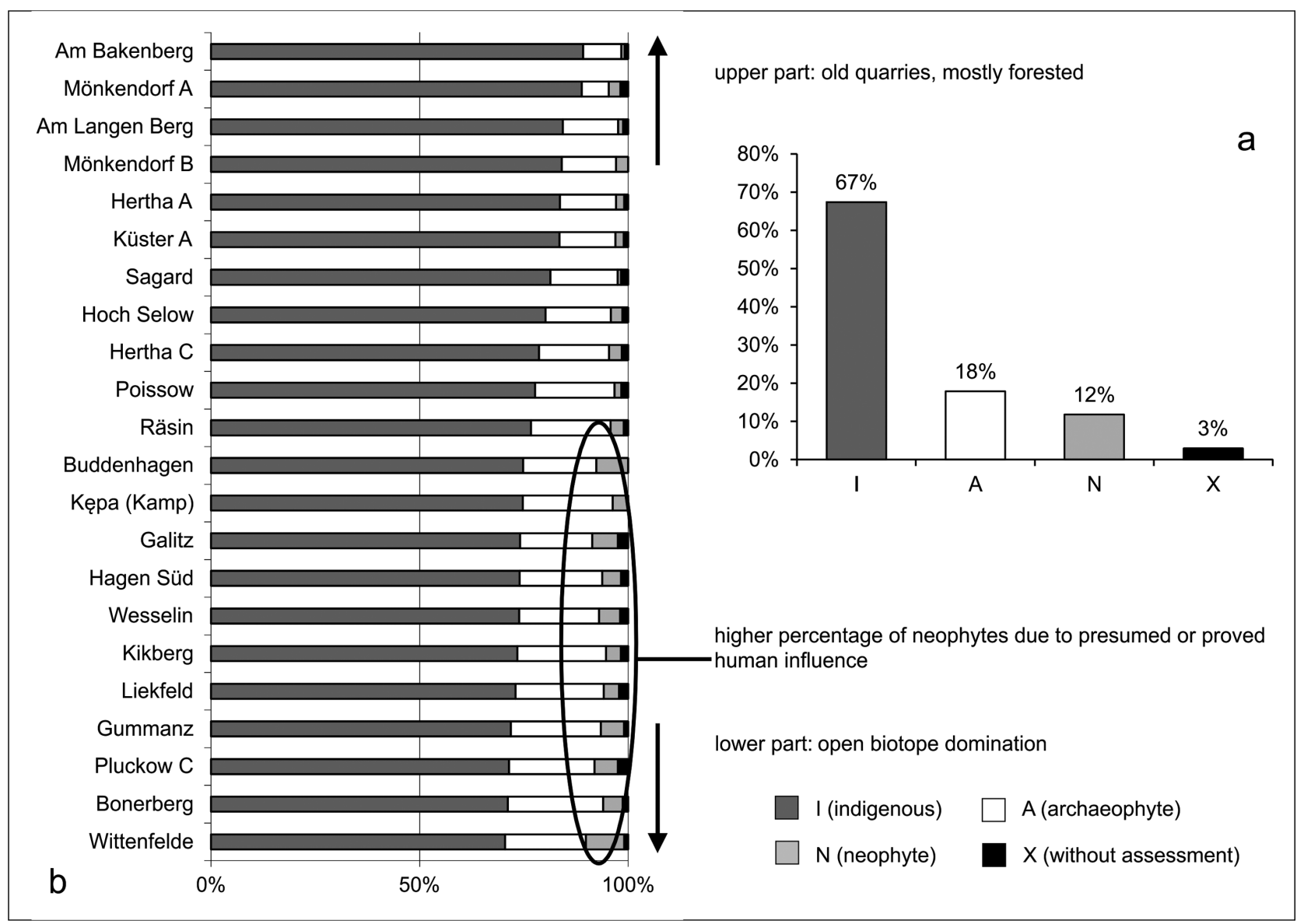

Fig. 5. Percentage of species in the Jasmund and Wolin chalk quarries according to their period of immigration or introduction to Mecklenburg-Western Pomerania (Fukarek \& Henker 2006), a - based on the total floristic inventory of 38 quarries $(\mathrm{n}=543), \mathrm{b}-$ for 22 selected quarries studied in detail ( $\mathrm{n}=483$ species)

\subsection{Endangered species}

According to the Red Data Book, the total floristic composition of 543 ferns and flowering plants (Fig. 6) shows a proportion of 100 species $(18.4 \%)$ designated as endangered in some way according to the compilation of Voigtländer \& Henker (2005) for MecklenburgWestern Pomerania. Looking at the 22 quarries analysed in greater detail (Fig. 7), the percentage of Red List species ranged from 3.7 to $23.5 \%$. Quarries with open

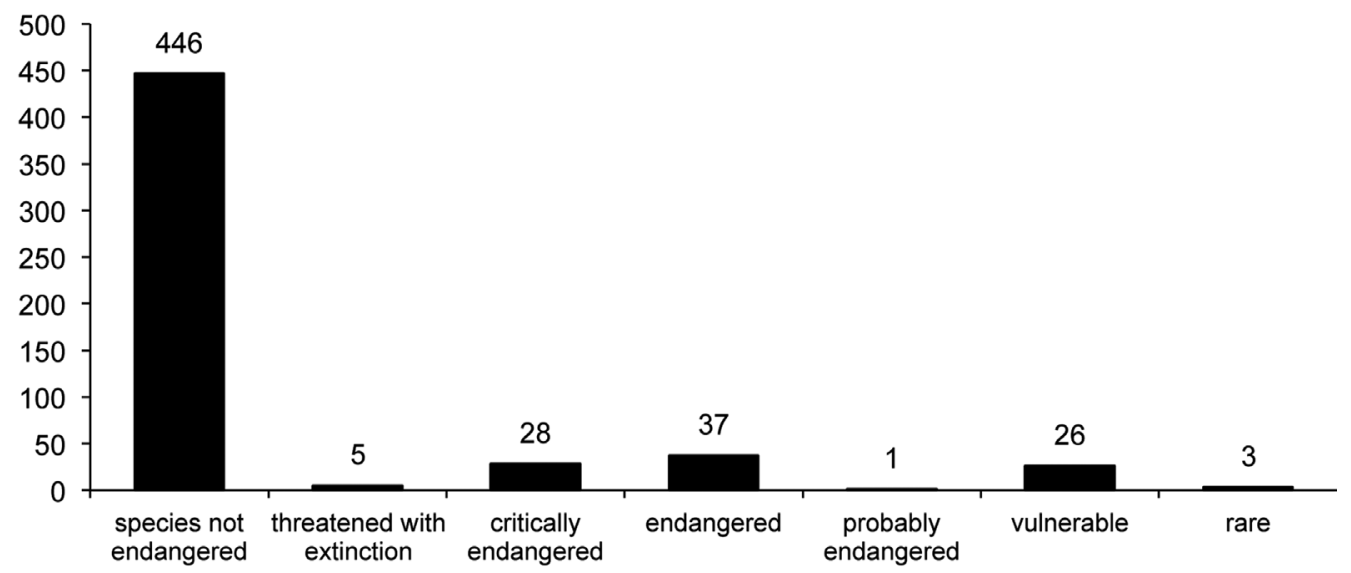

Fig. 6. Floristic inventory $(n=543)$ of Jasmund and Wolin chalk quarries and the proportions of Red List species of Mecklenburg-Western Pomerania (Voigtländer \& Henker 2005) 


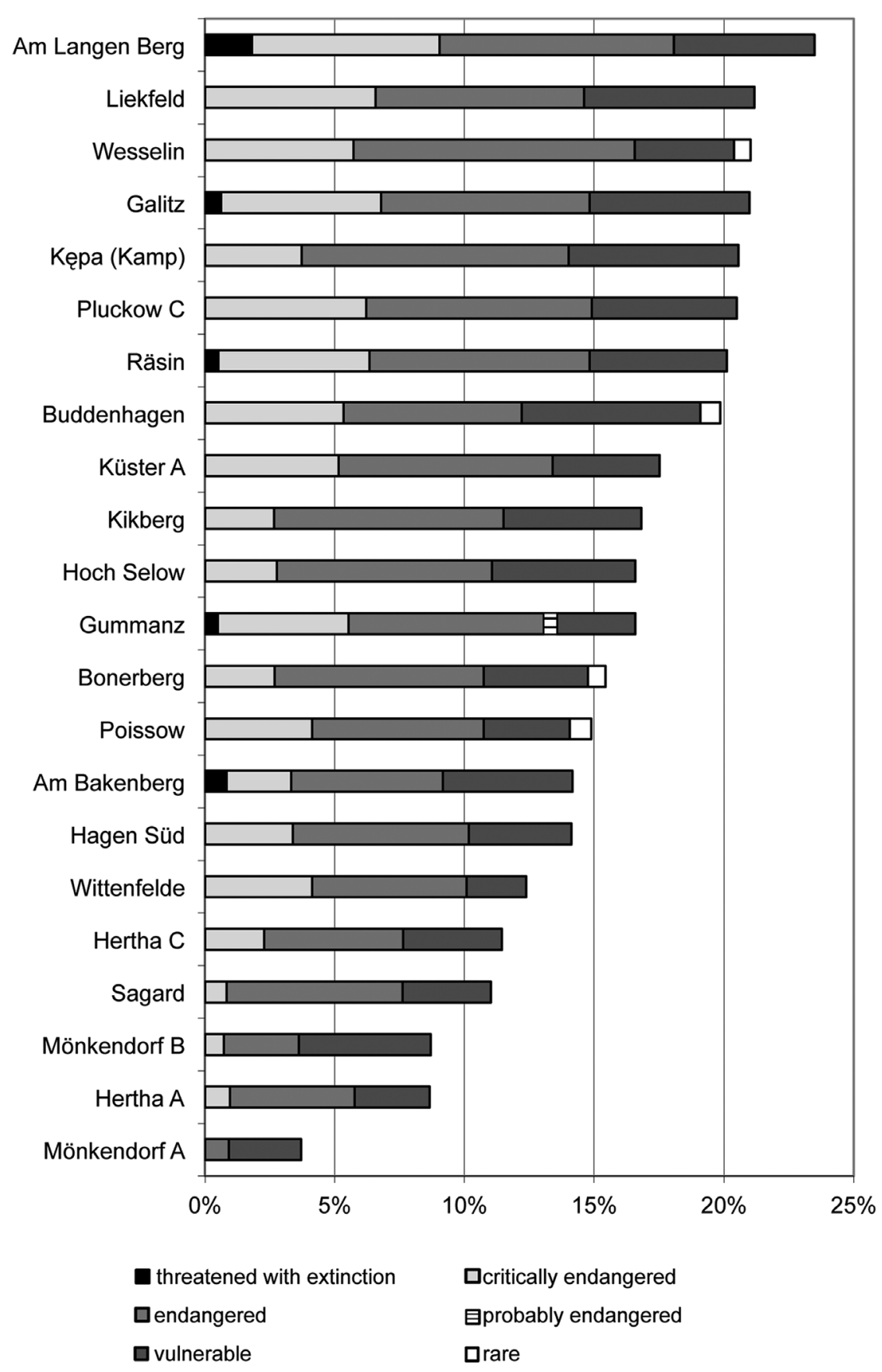

Fig. 7. Percentage of Red List species in the Jasmund and Wolin chalk quarries studied in detail (evaluation basis - Voigtländer \& Henker 2005)

habitats and considerable biotope diversity harboured the bulk of Red List species.

The relevance of vegetation types in the chalk quarries to nature conservation aspects is illustrated in Fig. 8. Obviously, the Anthropo-zoogenic heathland and grassland is of outstanding importance with $40 \%$ Red List species (i.e. 46 of 115). Some quarries have contact with the aquifer and are characterised by variously sized ponds and swampy areas. Due to nutrient-poor site conditions, a considerable amount of diversity is attributed to fresh water and bog vegetation, with a remarkable $29 \%$ of Red List species (i.e. 17 of 58 ).

\subsection{Vegetation}

Table 3 displays an overview of the plant sociological assignments of the species inventory according to Ellenberg (1992). Maximum values of 37.4\% were reached by the former quarry "Kępa (Kamp)", which was in surprisingly close contact to psammophytic vegetation and, thus, harboured species such as Armeria elongata, Asparagus officinalis, Berberis vulgaris, Centaurea stoebe, Corynephorus canescens, Dianthus carthusianorum, Helichrysum arenarium, Petrorhagia prolifera, Phleum phleoides, Silene otites, Thymus 


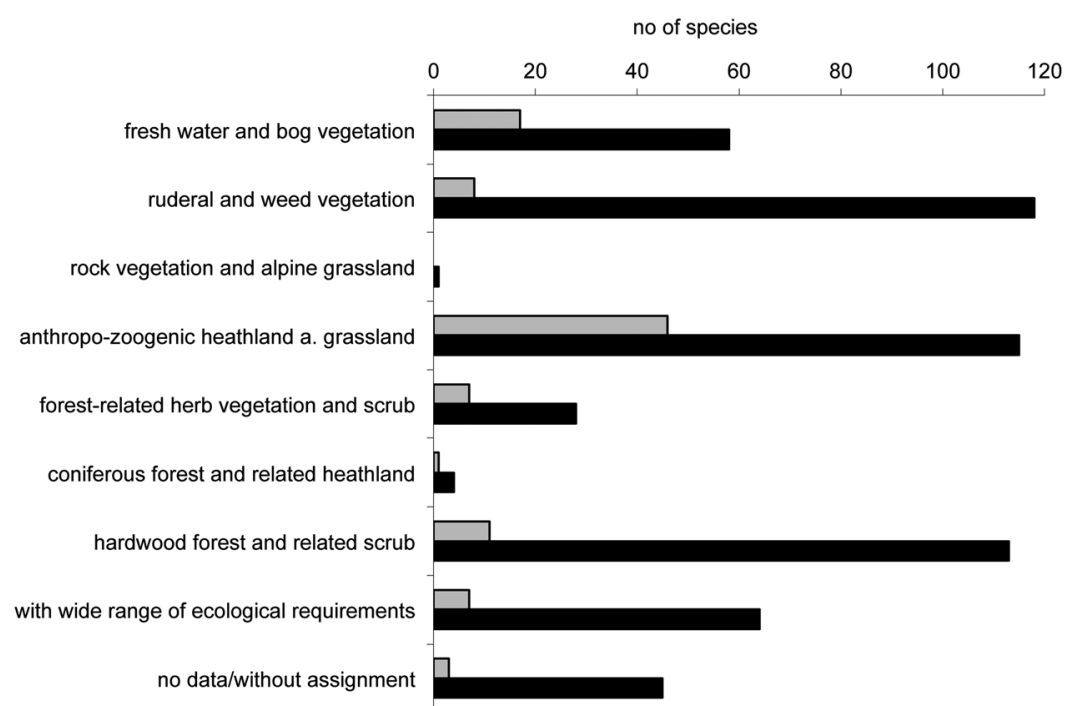

Fig. 8. Species of the Jasmund and Wolin chalk quarries with their affiliation to vegetation types (Ellenberg 1992) and the proportion of Red List species

Explanations: $\square$ - the total number of species affiliated to a given vegetation type, $\square-$ the number of Red List species (according to Voigtländer \& Henker 2005) affiliated to a given vegetation type

serpyllum and Verbascum densiflorum, contributing to the top position among the "Anthropo-zoogenic heathland and grassland". But even long-abandoned quarries such as "Mönkendorf A" or "Am Bakenberg" contained a relevant resources of about $20 \%$. Small patches of grassland, in an otherwise forested area, contributed to such quantitative data.

Species of "fresh water and bog vegetation" were present in nearly all quarries and constituted up to $15.2 \%$ in "Hoch Selow". Species belonging to "hardwood

Table 3. Percentage assignment of vegetation types (Ellenberg 1992) and number of species in the flora of Jasmund and Wolin chalk quarries studied in detail

\begin{tabular}{lcccccccccc}
\hline Quarry name (n=22) & 1 & 2 & 3 & 4 & 5 & 6 & 7 & 8 & 9 & 10 \\
\hline Am Bakenberg & 1.7 & 16.7 & 0.0 & 24.2 & 5.0 & 0.0 & $\mathbf{3 3 . 3}$ & 16.7 & 2.5 & 120 \\
Am Langen Berg & 1.2 & 13.3 & 0.0 & 33.1 & 4.8 & 0.6 & 28.3 & 15.7 & 3.0 & 166 \\
Bonerberg & 1.3 & 19.5 & 0.0 & 32.2 & 8.7 & 0.7 & 18.8 & 14.1 & 4.7 & 149 \\
Buddenhagen & 2.3 & 22.9 & 0.0 & 26.7 & 6.1 & 0.8 & 22.9 & 17.6 & 0.8 & 131 \\
Galitz & 7.4 & 16.0 & 0.0 & 30.2 & 8.6 & $\mathbf{1 . 2}$ & 20.4 & 12.3 & 3.7 & 162 \\
Gummanz & 7.0 & $\mathbf{2 6 . 6}$ & 0.0 & 28.1 & 6.5 & 0.0 & 16.6 & 12.1 & 3.0 & 199 \\
Hagen Süd & 2.8 & 20.3 & 0.0 & 29.9 & 6.2 & 0.0 & 22.0 & 14.7 & 4.0 & 177 \\
Hertha A & 12.5 & 19.2 & 0.0 & 27.9 & 5.8 & 0.0 & 18.3 & 13.5 & 2.9 & 104 \\
Hertha C & 6.1 & 22.9 & 0.0 & 32.8 & 6.1 & 0.0 & 15.3 & 15.3 & 1.5 & 131 \\
Hoch Selow & $\mathbf{1 5 . 2}$ & 19.4 & 0.5 & 27.6 & 3.7 & 0.5 & 17.5 & 13.4 & 2.3 & 217 \\
Kępa (Kamp) & 2.8 & 16.8 & 0.0 & $\mathbf{3 7 . 4}$ & 6.5 & 0.9 & 15.0 & 19.6 & 0.9 & 217 \\
Kikberg & 0.0 & 23.0 & 0.0 & 26.5 & 8.0 & 0.0 & 20.4 & 17.7 & 4.4 & 113 \\
Küster A & 4.1 & 15.5 & 0.0 & 27.8 & 7.2 & 1.0 & 25.8 & 16.5 & 2.1 & 97 \\
Liekfeld & 0.7 & 19.7 & 0.0 & 33.6 & 8.0 & 0.7 & 17.5 & 16.1 & 3.6 & 137 \\
Mönkendorf A & 13.0 & 21.3 & 0.0 & 18.5 & 4.6 & 0.0 & 30.6 & 12.0 & 0.0 & 108 \\
Mönkendorf B & 13.8 & 17.4 & 0.0 & 23.9 & 5.1 & 0.0 & 25.4 & 13.8 & 0.7 & 138 \\
Pluckow & 1.2 & 20.5 & 0.0 & 33.5 & 8.7 & 0.0 & 18.6 & 13.7 & 3.7 & 161 \\
Poissow & 5.0 & 24.0 & 0.0 & 30.6 & 6.6 & 0.0 & 17.4 & 13.2 & 3.3 & 121 \\
Räsin & 7.9 & 18.5 & 0.0 & 32.3 & 5.3 & 0.0 & 16.4 & 16.9 & 2.6 & 189 \\
Sagard & 6.8 & 22.0 & 0.0 & 25.4 & 5.1 & 0.0 & 22.0 & 14.4 & 4.2 & 118 \\
Wesselin & 1.9 & 16.6 & 0.0 & 30.6 & 7.6 & 0.0 & 22.3 & 16.6 & 4.5 & 107 \\
Wittenfelde & 7.8 & 24.0 & 0.0 & 24.9 & 8.3 & 0.9 & 16.6 & 13.8 & 3.7 & 157 \\
\hline
\end{tabular}

Explanations: 1 - fresh water and bog vegetation, 2 - ruderal and weed vegetation, 3 - rock vegetation and alpine grassland, 4 - anthropo-zoogenic heathland and grassland, 5 - forest-related herb vegetation and scrub, 6 - coniferous forest and related heathland, 7 - hardwood forest and related scrub, 8 - with wide range of ecological requirements, 9 - no data/without assignment, 10 - number of species; maxima of relevant vegetation types are highlighted in black and minima in grey 


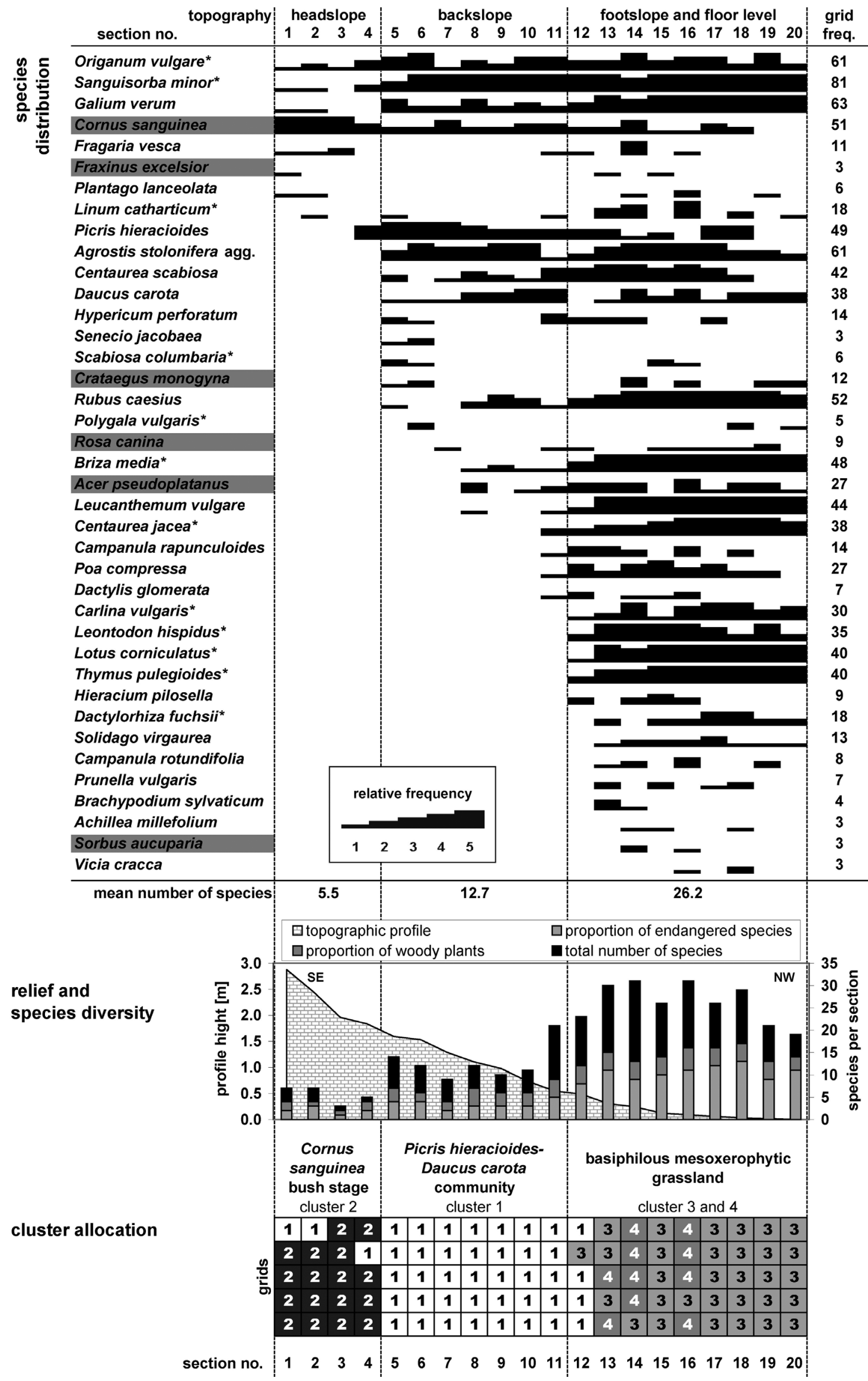

Fig. 9. Species distribution and ecological parameters along a transect in the Pluckow chalk quarry

Explanations: The following species with a grid frequency $<3$ are not displayed: Quercus robur (section 4/relative frequency in the transect 1, Tussilago farfara (11/1), Agrimonia eupatoria (13/1), Potentilla reptans (13/1), Silene vulgaris (13/1), Rhinanthus angustifolius* (17/1), Anagallis arvensis* (17/1, 18/1), Parnassia palustris* (17/1, 18/1); highlighted in grey - woody species, * - species classified in the Red Data Book of Mecklenburg-Western Pommerania (Voigtländer \& Henker 2005) 

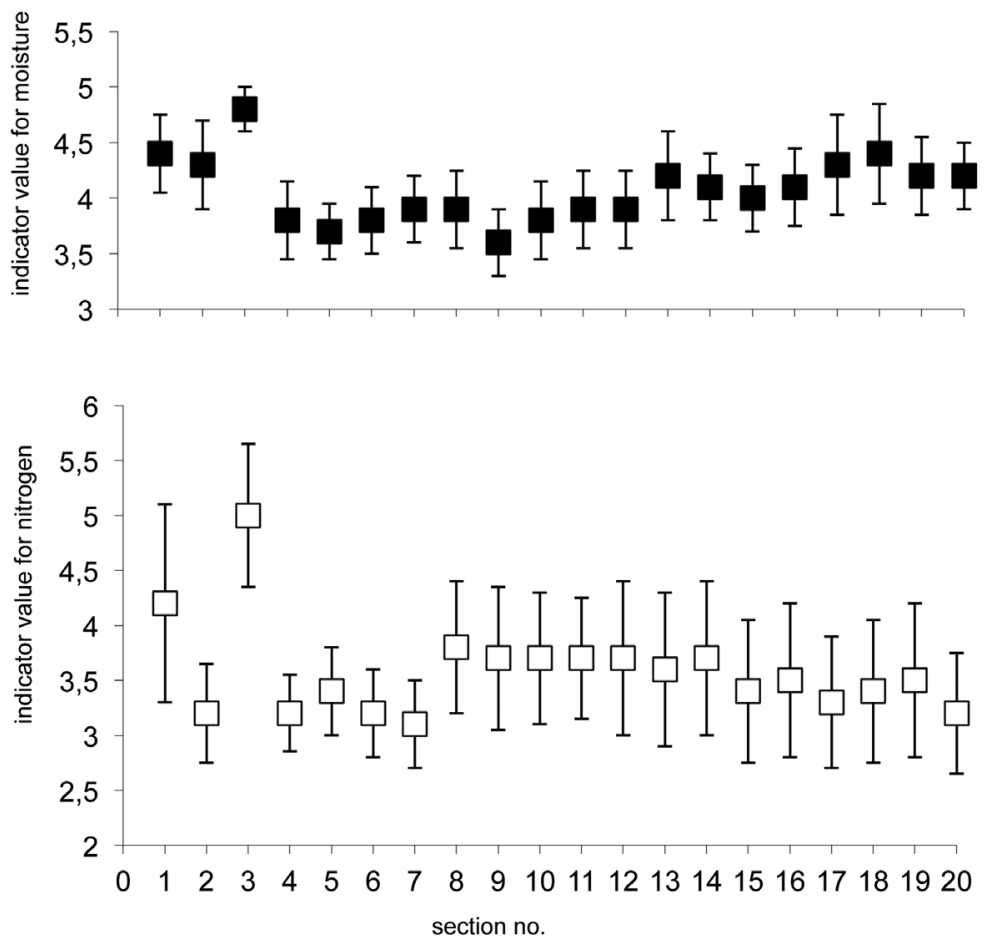

Fig. 10. Mean weighted Ellenberg (1992) indicator values (plus standard error) for moisture and nitrogen along the Pluckow transect

forest and related scrub" were dominant in quarries in close proximity to forests (e.g. "Am Langen Berg" $28.3 \%$, "Küster A" $25.8 \%$ ) or that had been abandoned long ago (e.g. "Am Bakenberg" 33.3\% - mining until 1925, "Mönkendorf A" 30.6\% - mining until 1910/20). The percentages of "ruderal and weed vegetation" ranged between 13.3 and $26.6 \%$. Higher percentages were characteristic of quarries with a relevant disturbance regime (e.g. former large-scale quarry "Wittenfelde" $24.0 \%$, "Gummanz" $26.6 \%$ due to pollution with agricultural waste in the 1980s) or, generally, with agricultural use nearby.

The vegetation zonation in the quarries is demonstrated exemplarily by the former mining area "Pluckow" (Fig. 9), which is embedded in an agricultural landscape. The species analysis, covering a $5 \mathrm{~m} \times 20 \mathrm{~m}$ transect along a slope with northwest exposure, showed a clear-cut sequence of three zones due to the relief: headslope, backslope, and footslope and floor level. The mean number of species per $1 \mathrm{~m} \times 5 \mathrm{~m}$ section increased from 5.5 to 12.7 and 26.2 from headslope to floor level. Thus, species diversity was not evenly distributed in a quarry. The woody species are highlighted separately (mostly only seedlings except for Cornus sanguinea and Rosa canina) and demonstrate the succession potential. Higher proportions of Red Data Book species were located in the footslope and floor level area.

A hierarchical cluster analysis and the related cluster allocation clearly identified the main vegetation com- munities (Fig. 9). The headslope was poor in species and Cornus sanguinea dominated the vegetation (C. sanguinea bush stage), accompanied by Fraxinus excelsior and some herbs (Fig. 9, Cluster 2). The backslope was more open, species diversity increasing and settled by a Picris hieracioides-Daucus carota (pioneer) community (Fig. 9, Cluster 1). Finally, the footslope and floor level harboured the bulk of species and was covered by a basiphilous mesoxerophytic grassland (Fig. 9, Cluster 3 and 4 , the latter with a higher percentage of woody plants).

As expected, the lime content of the topsoil $(0-10 \mathrm{~cm})$ was high, and ranged between $68.7 \% \pm 0.3$ (headslope), 78.1\% \pm 5.1 (backslope) and 75.5\% \pm 6.5 (footslope and floor level), thus mainly about $70-80 \%$ irrespective of the particular quarry zone. In contrast, the organic content of the topsoil $(0-10 \mathrm{~cm})$ was low $(1-2.5 \%)$ and varied from $2.2 \% \pm 0.3$ (headslope), to $1.4 \% \pm 0.4$ (backslope) and 3.6\% \pm 1.1 (footslope and floor level), thus reflecting the humus accumulation process in different successional stages.

Fig. 10 displays further abiotic site factors indirectly estimated on the basis of weighted averages of Ellenberg indicator values for moisture and nitrogen. The moisture values were highest in the headslope range, with a distinct decrease in transition to the upper backslope sections, and a continuous increase towards the footslope and floor level. The highest nitrogen values were depicted in the headslope area, while the lowest were centered in the upper backslope sections. 


\section{Discussion}

Small-scale quarries are historical monuments of former land use. These man-made areas are subject to secondary processes resulting in biotopes which are only temporarily available. 50-100 years are estimated for a forest to re-cover a disturbed site. The original primary processes creating open biotopes are observable in the erosion of chalk cliffs, e.g. in Jasmund National Park, Island of Rügen. Quarries enclosed either by forest or agricultural land are exposed to various input of diaspores and nutrients. Woody plants will take over in an accelerated process toward becoming shrub and forest communities in quarries bordering forests, and mesophytic grassland and perennial herb vegetation will develop in quarries in the vicinity of agricultural land. The succession in chalk ecosystems is represented by bare chalk-colonising species, chalk grassland, shrubs and, finally, forest, and to that extent corresponds to the situation in disused British quarries (Usher 1979).

Open sites or disturbances are provided by trampling by visitors and leisure activities (motorcycle racing, party events, fire). Furthermore, grazing by wildlife (e.g. browsing damage of young tree and shrub growth by deer is visible nearly everywhere) and maintenance work organised by the nature conservation authorities (removal of woody plant growth, mowing mainly in National Park and Natural Monument areas, e.g. König et al. 2005) are important factors to keep succession slow or to preserve specific colonisation stages. These are not only of botanical importance, but also provide various animals, e.g. butterflies, a reproduction facility and a stepping stone (Turner et al. 2009).

Davis (1979) was among the first to report chalk and limestone quarries as wildlife habitats, and presented the results of mapping ten British quarries aged from less than 15 years to about 100 years. These figures are mainly based on single visits and are known to be incomplete in several instances; nevertheless, the accumulated total was 267 species (excluding nine marsh plants), of which 108 were confined to single sites. The number of plant species ranged between 68 and 94 , and the individual quarry areas surveyed from 0.1 to 15 hectares (median 1.75 ha). Zerbe \& Schacht (1997) analysed six Jasmund chalk quarries and recorded 291 fern and flowering plants species, with the species diversity in the quarries ranging from 106 to 180 . The present study examined 22 quarries in more detail, resulting in a floristic resources of 483 vascular plant species, with individual quarry diversity between 97 and 218 depending on size and diversity of site conditions. The floristic total of all quarries observed reached 543 vascular plant species. Fig. 11 indicates that increasing numbers of studied quarries resulted in slowly rising species diversity.

The surveys of Jefferson (1984) and Wheater \& Cullen (1997) are based on random quadrat sampling (256 species in 26 sites or 103 species in 11 sites) and, thus, underperform the total floristic resources of the quarries.

Noteworthy proportions of associated neophytes are an indicator of anthropogenic impact (Hill et al. 2002). The total share of $12 \%$ neophytes agree with typical rural areas moderately influenced by humans (Ermer et al. 1996). The constancy of neophyte findings was often low and limited to single sites; thus, the overall evaluation approach led to a comparatively high percentage. A closer look at individual chalk quarries supports this assumption (Fig. 5b). The lowest percentage in indigenous species was about $70 \%$, e.g. in the quarry Wittenfelde (formerly mined on a large scale), while values increased to nearly $90 \%$ in quarries "untouched" for a long time and nowadays mostly forested.

In other words, quarries dominated by open biotopes, close vicinity to settlements, or with easy accessibility

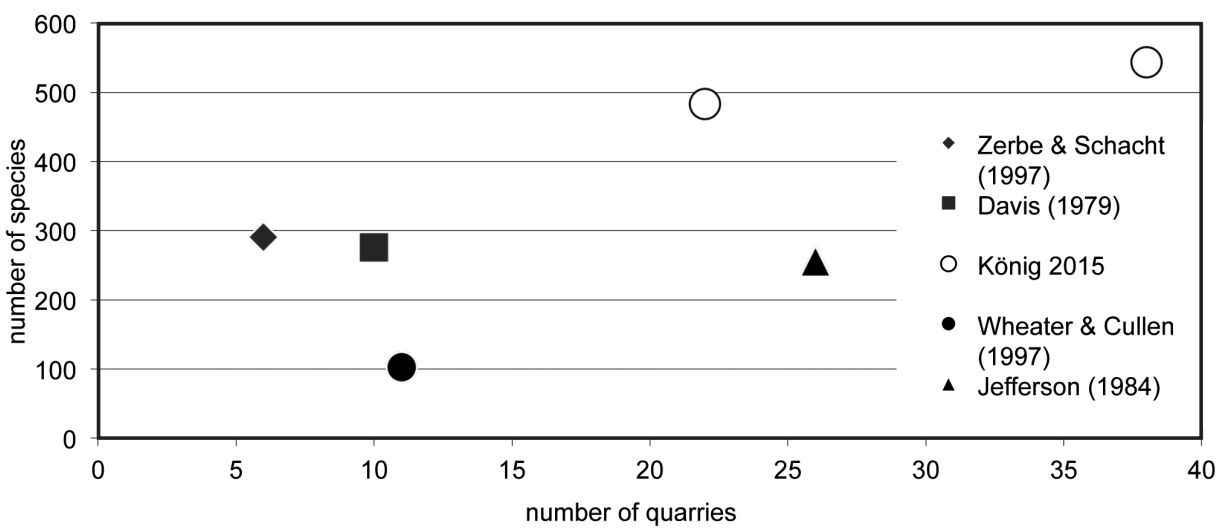

Fig. 11. The number of species in relation to the number of chalk quarries analysed

Explanation: Results of Jefferson (1984) and Wheater \& Cullen (1997) based only on random surveys with representative quadrats 
Table 4. Frequency of orchid species occurring in the 22 Jasmund and Wolin chalk quarries studied in detail

\begin{tabular}{lc}
\hline Species name & Frequency \\
\hline Dactylorhiza fuchsii & 18 \\
Epipactis palustris & 9 \\
Listera ovata & 9 \\
Epipactis atrorubens & 6 \\
Epipactis helleborine & 4 \\
Dactylorhiza majalis & 3 \\
Orchis mascula & 2 \\
Orchis militaris & 2 \\
Cephalanthera damasonium & 1 \\
Cephalanthera longifolia & 1 \\
Gymnadenia conopsea & 1 \\
Neottia nidus-avis & 1 \\
Cypripedium calceolus & 1 \\
\hline
\end{tabular}

Explanation: * - only replanted, establishment uncertain

may exhibit a higher percentage of neophytes due to human influence (Fig. 5b). Quarries abandoned long ago or contiguous with forest areas are at least partly forested and display a tendency to high proportions of indigenous species and lower neophyte percentages (Fig. 5b).

Many plants and animals are associated with open ground and pioneer conditions. Several species of orchids fall into this category and exert, apart from legal protection status, a particular fascination because of their attractive appearance and interesting biology. The orchids of Rügen Island found favour with various authors (Bürgener 1959; Knapp 1977; Kutscher 1983, 1997a). Kutscher (1997b) reports a reintroduction of Orchis militaris. Dactylorhiza fuchsii ranking among the species with high constancy (Table 4). Also Epipactis palustris, Listera ovata or Epipactis atrorubens are quite commonly found in disused quarries. Cephalanthera spp. and Neottia nidus-avis represent succession towards a forest canopy. Furthermore, chalk quarries are included in the discussion of second-hand biotopes for the critically endangered Cypripedium calceolus (Lady's Slipper Orchid). Ex situ specimens propagated at the Botanic Garden Rostock may find a future in suitable chalk quarries in the course of a resettlement program (Leipe 2013). Specimens in danger of loss through cliff slides have already been pre-emptively planted in one of the chalk quarries.

This is in line with Davis (1979), who collected data on orchid distribution during surveys of chalk and limestone quarries. Of a total of 144 quarries from 32 counties in England where vegetation surveys were made, 84 contained one or more species of orchid. The Common Spotted Orchid Dactylorhiza fuchsii was classified as usually the first orchid to colonise quarries and was the most widespread species as well.

Modern analyses of the genetic structure of orchid populations (e.g. Epipactis palustris in Eastern Germany, Orchis militaris in Estonia) reveal that there are no differences between genetic diversity values of populations from former mining areas and those of natural habitats (Esfeld et al. 2008; Ilves et al. 2015). In other words, previously mined areas function as conservation spots in addition to the protection of indigenous calcareous grasslands.

The proportion of endangered species in Jasmund chalk quarries was calculated at $12.4 \%$ (36 of 291 species, surveyed quarries $n=6$ ) by Zerbe $\&$ Schacht (1997) based on the 1991 Red Data Book of Fukarek (1992). Currently, Red Data Book species account for $19.5 \%$ (94 of 483 species, $n=22$ ), according to the latest evaluation by Voigtländer \& Henker (2005). The bulk of Red Data Book species are affiliated to Anthropozoogenic heathland and grassland (Fig. 8).

Table 5 displays the ratings according to the Red Lists of NW Poland (Żukowski \& Jackowiak 1995), Germany (Korneck et al. 1996), and Poland (Kaźmierczakowa et al. 2016) for comparison. It is obvious that the national lists of Germany and Poland

Table 5. Number and percentage of endangered fern and flowering plant species of German and Polish chalk quarries according to various rating sources

\begin{tabular}{|c|c|c|c|c|c|}
\hline \multirow{3}{*}{ Area } & \multirow{3}{*}{ Rating source } & \multicolumn{4}{|c|}{ Endangered species of chalk quarries surveyed } \\
\hline & & \multicolumn{2}{|c|}{$\begin{array}{c}\text { in detail } \\
\left(\mathrm{n}_{\text {quarries }}=22\right)\end{array}$} & \multicolumn{2}{|c|}{$\begin{array}{c}\text { in total } \\
\left(\mathrm{n}_{\text {quarries }}=38\right)\end{array}$} \\
\hline & & $\begin{array}{l}\text { No. of spp. } \\
\sum=483\end{array}$ & $\%$ & $\begin{array}{l}\text { No. of spp. } \\
\sum=543\end{array}$ & $\%$ \\
\hline Mecklenburg-Western Pomerania & Voigtländer \& Henker (2005) & 94 & 19.5 & 100 & 18.4 \\
\hline NW Poland & Żukowski \& Jackowiak (1995) & 29 & 6.0 & 30 & 5.5 \\
\hline Germany & Korneck et al. (1996) & 17 & 3.5 & 18 & 3.3 \\
\hline Poland & Kaźmierczakowa et al. (2016) & 14 & 2.9 & 15 & 2.8 \\
\hline
\end{tabular}


rate the total floristic inventory of the quarries $(n=38)$ at a comparatively low percentage of endangered vascular plants (3.3\% and $2.8 \%)$. On a regional scale, the affiliation to an endangerment category increases to 5.5\% (NW Poland) and 18.4\% (Mecklenburg-Western Pomerania).

Studies of the quarries vegetation zonation clearly indicate that species diversity is not evenly distributed in the quarries. The soil of the headslope was less disturbed, enriched in humus and covered by a comparatively dense vegetation. The backslope was affected by erosion processes and partly bare of vegetation, and the footslope was subject to a consolidation process. Foot slope and floor level were still open enough but more easy to settle compared to the backslope section and, consequently, contained the highest diversity (Jefferson \& Usher 1987; Zerbe \& Schacht 1998; König et al. 2005; Fig. 9).

Transects are placed free of any homogeneity aspects and allow the study of continuous coming and going of plants, and change of vegetation accordingly, along a quarry slope. The result of a statistical evaluation is the identification of rank-free vegetation communities and their relief-relevant location representing a particular quarry slope succession. In contrast, the approach of Zerbe \& Schacht (1998), using the classic Braun-Blanquet technique, requires homogenous sampling areas and allows a deductive presentation of successional events. Amalgamating both approaches for the presented transect, it can be stated that the Cornus sanguinea bush stage is phytosociologically affiliated to the Rhamno-Cornetum sanguinei, the Picris hieracioides-Daucus carota community to the DaucoPicridetum hieracioides (together with some slight relations to the Poo-Tussilaginetum farfarae), and the basiphilous mesoxerophytic grassland can be placed among the Mesobromion alliance.

Species indicator values offer, apart from some restrictions, a generally accepted complement for the determination of environmental variables (Diekmann 2003). Soil parameters, depicted by indicator values for moisture and nitrogen (Fig. 11a), reflect an enormous variation, especially in the transition from headslope to backslope, due to heterogeneous humus accumulation and shadow effect of Cornus sanguinea. The involved sections are poor in species, the environmental gradient is short and, thus, more seriously affected by random spatial fluctuation in species composition (Diekmann 2003). The driest sections are found in the upper part of the backslope, together with the lowest nitrogen values due to the occurrence of raw soil.

Abandoned quarries generally develop closed calcareous grassland or woodland conditions and, therefore, become less suitable for open-ground species. How can this be counteracted? The findings of Jefferson \&
Usher (1987) suggest that rotational scraping of small areas of the open species-rich quarry floor vegetation, removing surface soil and vegetation, may be the most appropriate management technique for maintaining nature conservation interest. Buried seeds could have important implications for management. The aim is to maintain species-rich communities akin to those of the region. If the succession is allowed to proceed too far, i.e. into a tall grassland invaded with scrub, it may be impossible to return to the open species-rich conditions, due to the nature of any secondary succession started as a result of management operations.

The two management techniques which could be used to arrest successional change in quarry sites are grazing and mowing. In reality, the former method is not always a practical solution due to the expense of fencing, the availability of livestock or the problem of providing drinking water. Similarly, mowing is not often a practical solution due to the uneven nature of the terrain and the unavailability of suitable equipment. As an alternative, management at British quarries (Jefferson \& Usher 1987) involved mechanical scraping and removal of both vegetation and surface soil from the underlying chalk with a view to restarting the succession. Results indicate that the scraped areas, at present, most closely resemble the species-rich community.

It remains open to discussion whether a society is able to protect and/or conserve a selected inventory of man-made biotopes or landscape types as part of its cultural heritage - like paintings in art galleries. Postmining landscapes provide distinctive and varied topographical forms compared to the surrounding area, and a region with a characteristic identity (Schmidt 2006).

Historical mining areas are part of the cultural landscape and provide habitats for a set of remarkable plants and plant communities. They form small islands within a landscape mostly dominated by agriculture and forestry. Together with the process-conservation areas of the cliffs in the National Parks of Jasmund and Wolin, they form stepping-stone biotopes for species preferring open soil. In periods of increased landslides, the importance of former chalk quarries as refugia is even more eminent. Kutscher (1997a: 86) assumes that the collection of large boulders from the Jasmund surf zone at the beginning of the $20^{\text {th }}$ century for construction purposes has resulted in the erosion of more gentle slopes, while steeper cliffs with difficult colonising potential remain.

For the northeast lowlands, the German Red Data Book on endangered habitats (Riecken et al. 2009) classifies "Abandoned post-mining waterbodies" as endangered to vulnerable depending on the nutrient supply (oligotrophic to eutrophic standing waters), and "semi-dry grassland on carbonate substrate" as endangered. 
Acknowledgements. Thanks to Manfred Kutscher and the Chalk Museum Gummanz for internal information concerning the quarry exploitation and succession processes. Anett
Stolte contributed to the field work and performed the soil analyses in the laboratory of the Institute of Botany and Landscape Ecology.

\section{References}

BACZyŃSKa A., Lorenc M. W. \& Kaźmierczak U. 2017. The landscape attractiveness of abandoned quarries. Geoheritage DOI 10.1007/s12371-017-0231-6.

Behrens G. 1878. Ueber die Kreideablagerungen auf der Insel Wollin. Zeitschrift der Deutschen Geologischen Gesellschaft 30: 229-267.

Beneš J., KePKa P. \& KonvičKa M. 2003. Limestone quarries as refuges for European xerophilious butterflies. Conserv Biol 17: 1058-1069.

BÜRGENER O. 1959. Rügens Orchideen einst und jetzt. Archiv d. Freunde d. Naturgeschichte in Mecklenburg 5: 184-194.

DAvis B. N. K. 1979. Chalk and limestone quarries as wildlife habitats. Minerals and the Environment 1: 48-56.

Diekmann M. 2003. Species indicator values as an important tool in applied plant ecology - a review. Basic Appl Ecol 4: 493-506.

EllenBerg H. 1992. Zeigerwerte der Gefäßpflanzen (ohne Rubus). In: H. Ellenberg, H. H. Weber, R. Düll, V. Wirth, W. Werner \& D. Paulissen (eds.). Zeigerwerte von Pflanzen in Mitteleuropa. $2^{\text {nd }}$ ed., Scripta Geobot. 18: 9-166.

Esfeld K., Hensen I., Wesche K., Jakob S., Tischew S. \& Blattner F. R. 2008. Molecular data indicate independent colonizations of former lignite mining areas in Eastern Germany by Epipactis palustris (Orchidaceae). Biodivers Conserv 17: 2441-2453.

Ermer K., Hoff R. \& Mohrmann R. 1996. Landschaftsplanung in der Stadt. 304 pp. Ulmer, Stuttgart.

FukAReK F. 1992. Rote Liste der gefährdeten Höheren Pflanzen Mecklenburg-Vorpommerns (4. Fassung, Stand: Oktober 1991). 64 pp., Umweltministerin des Landes Mecklenburg-Vorpommern, Schwerin.

Fukarek F. \& Henker H. 2006. Flora von MecklenburgVorpommern - Farn- und Blütenpflanzen. 428 pp. Weissdorn, Jena.

Hill M. O., Roy D. B. \& Thompson K. 2002. Hemeroby, urbanity and ruderality: bioindicators of disturbance and human impact. J Appl Ecol 39: 708-720.

Ilves A., Metsare M., Tali K. \& Kull T. 2015. The impact of recent colonization on the genetic diversity and fine-scale genetic structure in Orchis militaris (L.). Plant Syst Evol 301: 1875-1886.

JÄGER E. J. (ed.). 2011. Rothmaler - Exkursionsflora von Deutschland. Gefäßpflanzen: Grundband. 20. ed. 930 pp. Spektrum, Heidelberg.

JEFFERSON R. G. 1984. Quarries and wildlife conservation in the Yorkshire Wolds, England. Biol Conserv 29: 363-380.

JefFerson R. G. \& Usher M. B. 1987. The seed bank in soils of disused chalk quarries in the Yorkshire Wolds,
England. Implications for conservation management. Biol Conserv 42: 287-302.

JefFerson R. G. \& Usher M. B. 1989. Seed rain dynamics in disused chalk quarries in the Yorkshire Wolds, England, with special reference to nature conservation. Biol Conserv 47: 123-136.

Kaźmierczakowa R., Bloch-OrŁowska J., Celka Z., Cwener A., Dajdok Z., Michalska-Hejduk D., Pawlikowski P., SzCZÉŚniaK E. \& ZiARneK K. 2016. Polish red list of pteridophytes and flowering plants. $44 \mathrm{pp}$. Instytut Ochrony Przyrody Polskiej Akademii Nauk, Kraków.

KNAPP H.D. 1977. Die Orchideen der Insel Rügen. Ber. Arbeitskrs. Heim. Orchid. 7: 17-48.

Kосн M. 1934. Zur Geschichte von Saßnitz. 139 pp. Author's edition, Saßnitz.

König P., Böttcher A. \& Steffenhagen P. 2005. Der ehemalige Kreidebruch Hoch Selow (Halbinsel Jasmund/ Rügen) - ein Beitrag zum Zustand und zur Pflege von Kulturlandschaftsbestandteilen. Naturschutzarbeit in Mecklenburg-Vorpommern 48(1): 34-40.

Korneck D., Schnittler M. \& Vollmer I. 1996. Rote Liste der Farn- und Blütenpflanzen (Pteridophyta et Spermatophyta) Deutschlands. Schriftenreihe für Vegetationskunde 28: 21-187.

Kutscher M. 1983. Bemerkungen zu den Orchideen der Insel Rügen. Natur u. Umwelt, Beitr. Bez. Rostock 5: 66-70.

Kutscher M. 1997a. Die Orchideen der Insel Rügen. Ber. Arbeitskrs. Heim. Orchid. 14(1): 83-101.

KuTSCHER M. 1997b. Über einen Ansamungsversuch von Orchis militaris L. Ber. Arbeitskrs. Heim. Orch. 14(2): 71-76.

KutsCher M. 1998. Insel Rügen. Die Kreide. 57 pp. Verein der Freunde und Förderer des Nationalparkes Jasmund, Sassnitz.

LeIPE S. 2013. Bericht zur 41. Vortragstagung der AG Geobotanik in Neubrandenburg. Bot. Rundbr. für Mecklenburg-Vorpommern 50: 133-136.

Mirek Z., Piękoś-Mirkowa H., Zając A. \& Zając M. 2002. Flowering plants and pteridophytes of Poland. A checklist. In: Z. MireK (ed.). Biodiversity of Poland, 1, 442 pp. W. Szafer Institute of Botany, Polish Academy of Sciences, Kraków.

PRACH K. \& PYŠEK P. 2001. Using spontaneous succession for restoration of human-disturbed habitats: Experience from central Europe. Ecol Eng 17: 55-62.

ReIch M. 2001. Pravuscucumis deeckei paragen. et parasp. nov. (Echinodermata: Holothuroidea) aus dem Turonium des Ostseegebietes. Geschiebekunde aktuell 17(2/3): 97-106.

Reich M. \& Wiese F. 2010. Apodid sea cucumbers (Echinodermata: Holothuroidea) from the Upper Turonian of 
the Isle of Wolin, NW Poland. Cretaceous Research 31: 350-363.

Riecken U., Finck P., Raths U., Schröder E. \& Ssymank A. 2009. German Red Data Book on endangered habitats. 18 pp. Federal Agency for Nature Conservation (BfN), Bonn-Bad Godesberg.

Schlichting E., Blume H.-P. \& Stahr K. 1995. Bodenkundliches Praktikum. Eine Einführung in pedologisches Arbeiten für Ökologen, insbesondere Land- und Forstwirte, und für Geowissenschaftler. $2^{\text {nd }}$ ed. 295 pp. Blackwell, Berlin \& Wien.

Schmidt C. 2006. Das Kulturlandschaftsprojekt Ostthüringen. Forschungs- und Sitzungsberichte der ARL 228: 150-181.

Tischew S. \& Kirmer A. 2007. Application of basic studies in restoration ecology: success and deficiencies in the ecological restoration of surface-mined land in eastern Germany. Restor Ecol 15: 321-325.

Turner E. C., Granroth H. M. V., Johnson H. R., Lucas C. B. H., Thompson A. M., Froy A. M., German R. N. \& Holdgate R. 2009. Habitat preference and dispersal of the Duke of Burgundy butterfly (Hamearis lucina) on an abandoned chalk quarry in Bedfordshire, UK. J Insect Conserv 13: 475-486.

UsHer M. B. 1979. Natural communities of plants and animals in disused quarries. J Environ Manage 8: 223-236.

Voigtländer U. \& Henker H. 2005. Rote Liste der Farnund Blütenpflanzen Mecklenburg-Vorpommerns, 5.
Fassung. 59 pp. Umweltministerium MecklenburgVorpommern, Schwerin.

Weber E. 1956. Die Kreideindustrie Rügens. Natur und Heimat 1956/9: 274-277.

Weber E. 1970. Die Entwicklung der rügenschen Kreideindustrie bis zum Ersten Weltkrieg. Jahrbuch für Wirtschaftsgeschichte 1970/2: 101-128.

Wheater C. P. \& Cullen W. R. 1997. The flora and invertebrate fauna of abandoned limestone quarries in Derbyshire, United Kingdom. Restor Ecol 5: 77-84.

Wheater C. P., Cullen W. R. \& Bell J. R. 2000. Spider communities as tools in monitoring reclaimed limestone quarry landforms. Landscape Ecol 15: 401-406.

Zerbe S. \& Schacht T. 1997. Kreidebrüche auf Jasmund (Insel Rügen). Nutzungsgeschichte, Vegetation und Naturschutzaspekte. Naturschutz und Landschaftsplanung 29: 325-330.

Zerbe S. \& Schacht T. 1998. Vegetation and successional stages in chalk quarries on Jasmund (Rügen Island, NE Germany). Fragm Flor Geobot 43: 117-146.

ŻUKOWSKI W. \& JACKOWIAK B. 1995. List of endangered and threatened vascular plants in Western Pomerania and Wielkopolska (Great Poland). In: W. Żukowski \& B. JACKOWIAK (eds.). Endangered and threatened vascular plants of Western Pomerania and Wielkopolska. Publications of the Department of Plant Taxonomy of the Adam Mickiewicz University in Poznań 3: 9-96. Bogucki Wyd. Nauk., Poznań. 